\title{
EXISTÊNCIAS INFAMES E NOMES SECRETOS: A PARTIR DE A HERMENÊUTICA DO SUJEITO, DE MICHEL FOUCAULT
}

Júlia Vasconcelos STUDART

(Universidade. Federal de Santa Catarina)

RESUMO: Este texto parte do livro de Michel Foucault A Hermenêutica do sujeito, para armar uma série possível de leitura de algum movimento que está em certa narrativa brasileira que se desdobra em problemas da literatura e do sujeito contemporâneos. Mais especificamente, retomar aqui um impasse, quando se diz de certa experiência deste sujeito contemporâneo consigo, com o outro, com o mundo (se numa abrangência generalizada como política, num mover propositivo: como estar no mundo) e com a própria literatura. Assim, esse texto gera uma discussão sobre o caráter da experiência contemporânea, como vida infame, como devir e também como elemento questionador do lugar da literatura como problema, como experiência e como experiência textual, discurso etc, sempre como um gesto radical ao que seria a experiência pura, como um estatuto original da experiência.

PALAVRAS-CHAVE: Experiência; vida infame; devir

ABSTRACT: This text is based on Michel Foucault's book The Hermeneutics of the subject, in order to assemble a possible series of reading of a movement that is in some Brazilian narrative unfolded in problems of contemporary literature and subject. Specifically, it is to carry on, here, an impasse, when it is said about some experience of this contemporary subject with himself, with the other, with the world (if in a general scope as policy, in a propositive move: as being in the world) and with the literature itself. Thus, this text creates a discussion about the character of the contemporary experience, as infamous life, as devir and also as questioning element about the place of literature as problem, as experience and textual experience, discourse, etc, always as a radical gesture that would be the pure experience, like an original statute of experience. 
KEYWORDS: Experience; infamous life; devir

\section{INTRODUÇÃO: AS FORMAS DE EXPERIÊNCIA}

Este texto, numa sugestão ou inquietação, parte do livro de Michel Foucault A Hermenêutica do sujeito, para construir uma série possível de leitura, numa linha de perspectiva, de algum movimento entorno a determinados aspectós de certa narrativa brasileira que se monta e se desdobra em problemas da literatura e do sujeito contemporâneos. Mais especificamente, tento retomar aqui um impasse, um nó, quando se diz de certa experiência deste sujeito contemporâneo consigo, com o outro, com o mundo (se numa abrangência generalizada como política, num certo tom e mover propositivo: como estar no mundo) e com a própria literatura. E então, primeiro, para atravessar essa conversa, uma possível linha de tensão, partir de uma leitura que a primeira vista pode até parecer muito simples: as aulas de Michel Foucault no College de France, no ano de 1982, que resultaram neste Hermenêutica do sujeito, que - num meu resumo grosseiro - diz uma história das técnicas de existência desenvolvidas pela Antiguidade grega e romana, de um possível sujeito verdadeiro como lugar e experiência, no sentido de uma subjetivação, de uma estética da existência ou de uma tenúncia a si num gesto de decifração de sua própria verdade, algo como uma escolha ou uma marca para uma escolha. Ou, ainda, mais radicalmente, um sujeito que teima em inscrever-se numa ordem, tomando uma ordem para a própria vida, numa possibilidade de se fazer como fenda, como uma dobra, ou como diz Gilles Deleuze em seu livro Foucault (2005, p.107-108), de "vergar o lado de fora, em exercícios práticos". Enfim, Foucault apresenta um texto esticado a partir de suas aulas e dentro delas naquilo que pode ser lido e pensado (o que uso aqui) como uma narrativa sobre as formas de experiênicia.
Assim, este último e particular Foucault das revisões sobre o "cuidado de si" e o "conhecimento de si", sobre a constituição de uma "ética do eu", mesmo que ainda e sempre o mesmo das inquietações acerca do sujeito e do pensamento ${ }^{1}$, termina por retomar uma dimensão da subjetividade que possivelmente possa derivar de uma variedade de relações entre poder e saber, mas também numa dimensão que teima na dobta, num pensamento que lhe é exterior, e insiste num "fora" - que pode ser lido aqui, assim como a leitura que faz Maurice Blanchot, em $O$ livro por vir, como deserto, "esse lugar sem lugar que é o único lugar onde a alianca pode ser concluida e onde é necessário regressar sempre, como àquele momento de nudez $e$ de arrancamento que está na origem da existência justa." (BLANCHOT, 1984, p.88). É esta "existência justa", que é também uma existência móvel, que constitui uma relação de independência a essas forças, como se contra elas ainda restassem pontos de resistência ou, como sugere Deleuze, "um afeto de si para consigo, ou a força dobrada, vergada" (2005, p.111). E como todo procedimento de Foucault, ele termina operando como se desferisse pequenos cortes na história,

\footnotetext{
${ }^{1}$ Basta lembrar aqui as reflexões de Foucault acerca do que chama o "pensamento exterior", como discurso do limite, também gesto-ausência daquele que fala, um pensamento abandonado à interioridade que se torna "energia matetial, sofrimento da carne, perseguição e separação do sujeito mesmo", como por exemplo, os monólogos de Sade, a poesia de Hölderlin, de uma certa maneira, e a de Mallarmé, de outra maneira, ou as expetiências de Bataille com o texto. Um discurso que, segundo Michel Foucault, está além de toda linguagem, feito silêncio, ou nada. Cito: "Este pensamento que se mantém fora de toda a subjetividade para fazer surgir como do exterior seus limites, enunciar seu fim, fazer brilhar sua dispersão e não obter mais do que sua irrefutável ausência e que ao mesmo tempo se mantém no princípio de toda a positividade, não tanto para extrair seu fundamento ou sua justificativa, quanto para encontrar o espaço em que se desvincula o vazio que the serve de lugar, à distância em que se constitui e na qual se dissipam, desde o momento em que é objeto da mirada, suas certezas imediatas, - este pensamento, com relação à positividade do nosso saber, constitui o que poderiamos chamar em uma palavra 'o pensamento exterior'." (O pensamento do exteriot. Tradução Nurimar Falci. São Paulo: Editora Princípio, 1990. págs. 20 -22)
} 
pequenas perturbações no prumo da história, como um vetor, para apontar sempre interrogativas acerca deste sujeito, numa alteração ao seu estar no mundo. É como se o que ficasse (ou reverberasse), ainda, de resto, fosse alguma coisa parecida como a interrogativa de Deleuze: "o que é que sobra para nossa subjetividade?" Ao que ele mesmo responde: "Nunca sobra nada para o sujeito, pois, a cada vez, ele está por se fazer, como um foco de resistência, segundo a orientação das dobras que subjetivam o saber e recurvam o poder" (2005, p.113). Afinal, o que se impõe é uma mesma peleja: qual experiência possível? E se assim, partindo da experiência como procedimento, outra proposição parece se fazer sozinha neste percurso: qual dobra possivel? O que em Michel Foucault, me parece - uma dobra possível como resistência política, como vinca, como experiência, como constituição de um sujeito ético também possível - pode se dar, principalmente, numa telação de si para consigo, em como esse sujeito se organiza eticamente. Cito Foucault, em A hermenêutica do sujeito:

Parece-me não haver muito do que nos orgulharmos nos esforços que hoje fazemos para reconstituir uma ética do eu. E é possível que nestes tantos empenhos para reconstituir uma ética do eu, nesta série de esforços mais ou menos estanques, fixados em si mesmos, neste movimento que hoje nos leva, ao mesmo tempo, a nos referir incessantemente a esta ética do eu sem contudo jamais fornecer-lhe qualquer conteúdo, é possível suspeitar que haja uma certa impossibilidade de constituir hoje uma ética do eu, quando talvez seja esta uma tarefa urgente, fundamental, politicamente indispensável, se for verdade que, afinal, não há outro ponto, primeiro e último, de resistência ao poder político senão na relação de si para consigo (FOUCAULT, 2004, p. 304).

Penso ainda num outro Foucault, em $\mathbf{A}$ vida dos homens infames, nas "existências-clarão", ou numa outra dista, nos

${ }^{2}$ Essas expressões são do próprio Michel Foucault, retiradas do seu texto $A$ vida dos" bomens infames, quando se refere a estas existências infames. "poemas-vida", que são como os homens infames, essas existências flutuantes, esses quase, esses pouco-menos, esses "ajudantes" - como diz Giorgio Agamben quando fala algumas das personagens de Kafka:

En las novelas de Kafka vienem a nuestro encontro criaturas que se definem como "ayudantes" (Gebiffen). Pero en verdad ellas no parecen estar en condiciones de dar ninguna ayuda. No entienden nada, no tienen 'instrumentos', no hacen más que combinat tonterias com chiquilinadas, son 'molestos' y encima a veces 'descarados' y 'lascivos'. En cuanto a su aspecto, son tan parecidos que se distinguem solamente por el nombre (Arturo, Jeremias), se asemejan 'como serpientes'. [...] Alguno, no se sabe bien quién, nos los ha asignado y no es fácil sacárselos de encima. En suma, 'nosotros no sabemos quiénes son', acaso son los 'enviados' del enemigo (lo cual explicaria porqué no hacen outra cosa que apostarse y espiar). (AGAMBEN, 2005, p.37)

Desta forma, todos destinados a não deixar o menor rastro de experiência - tanto se como incorporação ou como um dado de uma cultura -, mas talvez deixar apenas algum vestígio terrivel e sutil de existência, uma mínima inscrição, que seja, do seu estar no mundo, estas suas existências-resto. Agamben (2005, p.40) ainda completa dizendo que vivem "inclusos entre las cosas", e que são uns "objetos inutiles, mitad recuerdo, mitad talismán". E ainda que o ajudante seria a "figura de lo que se pierde", algo como "todo aquello que, tanto en la vida colectiva como en la individual, se olvida a cada instante; se refiere a la masa infinita de lo que de por si se pierde irremediablemente. A cada instante, la medida del olvido y de la ruína, el derroche ontológico [...]" (2005, p.43). E para propor uma espécie de subjetividade a estes ajudantes, como uma força possível de existência, de experiência, de cultura e algum sentido para uma ontologia, diz, por fim, que constituem "una fuerza y casi una invectiva de lo olvidado que no se puede medirse en términos de conciencia ni ser acumulado como un patrimônio, pero cuya insistencia determina el rango de todo saber y de toda conciencia" (2005, p.44). Agamben vai lembrar o "corcundinha", "o inquilino 
de vida torta", das memótias infantis de Walter Benjamin, que aparece num relato de Rua de Mão Única, "O Corcundinha", e também é citado por Benjamin em seu texto sobre $\mathrm{Kafka}^{3}$, quando diz que "O homenzinho corcunda concretiza esta relação. O homenzinho é o habitante da vida deformada" (BENJAMIN, 1994, p.159). E Benjamin vai confirmat esta questão da experiência moderna como um sintoma, se posso dizer assim, da deformação da vida que se apresenta nestas personagens infames e de nomes secretos, como o corcundinha, e ao dizer mais radicalmente o Odradek de Kaflka, talvez a personagem de vida infame mais interessante que o autor tcheco construiu, e um pouco acerca de Gregor Samsa, a conhecida personagem-protagonista-inseto-monstruoso de $\mathbf{A}$ metamorfose, e montando também um discurso de reviravolta ao seu "corcundinha":

Odradek é o aspecto assumido pelas coisas em estado de esquecimento. Elas são deformadas. Deformada é a "preocupação do pai de familia", que ninguém sabe em que consiste, deformado o inseto, que como sabemos é na realidade Gregor Samsa, deformado o grande animal, meio carneiro e meio gato, para o qual talvez "a faca do carniceito fosse uma salvação". Mas esses personagens de Kafka se associam, através de uma longa série de figuras, com a figura primordial da deformação, o corcunda. Entre as atitudes descritas por Kafka em suas narrativas nenhuma é mais freqüente que a do homem cuja cabeça se inclina profundamente sobre seu peito. (BENJAMIN, 1994, p.158)

Assim, é importante dizer que o que Benjamin chama de experiência seria aquilo que nos entra como incorporação, aquilo que nos está como uma imagem de aderência; grosso modo, diz que de um lado, a erfabrung, que seria a experiência acumulada, a que se prolonga e se desdobra, uma sedimentação das coisas a partir de

${ }^{3}$ Este texto está publicado na edição brasileira intitulada Magia e técnica, Arte e . Política (São Paulo: Brasiliense, 1985) e é intitulado Franz Kaffea: $A$ propósito do décimo aniversário de sua morte, páginas 137 / 164. uma idéia do tempo dilatado; e do outro lado, a erlebnis, que seria a experiência interior, um evento assistido pela consciência, a experiência como uma duração pura do tempo vivido que produz um efeito imediato. Para exemplo, em seu Imagens do Pensamento, sobre Moscou, Benjamin diz dos mendigos que "entre todas as instituições de Moscou, eles são os únicos de confiança e que afirmam invariavelmente sua posição, enquanto, ao redor, tudo se desloca." (1985. p.164). Ou seja, Benjamin está tomando o mendigo como o sujeito da experiência, aquele que se fixa, que se aponta para o que incorpora da cidade como uma posse, uma tradição, uma história: tempo vivido como tempo interior mas também como experiência acumulada, desdobrada numa vivência. Ao mesmo tempo que, numa imagem dialética, aquilo que se move, que se desloca, ou descola, é o que poderia instar um outro sentido para a experiência, o instante, aquilo que poderia alterar e perturbar a história pré-fabricada, um recontar da história da cidade através da figura de seus mendigos.

Provável, como uma possibilidade, ainda, pensar esta idéia da experiência moderna benjaminiana esticada ao sujeito contempotâneo, pois, seguindo agora as pistas de Foucault, numa outra forma de experiência, das experiências-limite que se dão nas insignificâncias da vida mais ordinária, nos excessos de tudo - dos delitos, das paixões, dos segredos etc -, no interdito do mundo. Estas vidas infames, tortas, possivelmente estão ligadas a nomes secretos, palavras secretas, àquilo a que não se pode dizer, que estando ali pode também não estar. $E$ assim, talvez se possa pesar qualquer vestígio de experiência, um risco que seja, uma aventura, aquilo que possa causar alguma aderência ao corpo, à vida. Cito Foucault sobre estas vidas infames:

[...] que pertencessem àqueles milhões de existências que estão destinadas a não deixar rastro; que, nas suas infelicidades, nas suas paixões, naqueles amores e naqueles ódios, houvesse algo de cinzento e de ordinário aos olhos daquilo que habitualmente temos por digno de ser relatado; que, contudo, tenham sido atravessados por um

$\begin{array}{llll}\text { Rev. MOARA Belém } & \text { n. } 31 & \text { p. } 127-150 \quad \text { jan./jun, } 2009 .\end{array}$


certo ardor, que tenham sido animados por uma violência, uma energia, um excesso na malvadez, na vilania, na baixeza, na obstinação ou no infortúnio, tais que lhes proporcionassem, aos olhos daqueles que os rodeavam, e à medida de sua própria medioctidade, uma espécie de medonha ou lamentável grandeza (FOUCAULT, 1992, p. 96-97).

Este discurso da infâmia, da vileza, dos sem glótia, dessas existências attavessadas por um certo ardor e pela violência da vida, como ato, de alguma maneira, mesmo que com menos força que os atquivos de reclusão, das petições ao rei, das lettres de cachet do século XVII que tanto fascinaram Foucault - até porque não havia neles nenhum sentido aparente, ou todos, de fabulação, como também o que repousa em segredo, no sentido mesmo de um silêncio inviolável - compõem uma tradição da literatura no ocidente, um habito desta certa tradição ou, como menciona o próprio Foucault, para estabelecer o que setia uma espécie de "ética imanente ao discurso literário do Ocidente" (1992, p.125). Neste sentido, que trazem para o texto aquilo que seria mais difícil de ver, e tocar: o delito, o insignificante, o consumido, o anódino, o quase morto, o mudo e o sem fala, o não-tátil, o sem tiques ou o sem nenhuma nervura possível. Mas que, se fica sabido, ali está também o "dever de dizer o mais comuns dos segredos". Desta forma, seria como repetir inúmeras vezes a formulação de Beckett, repisada tantas vezes por Foucault, ptincipalmente em seu texto $\mathbf{O}$ que é um autor?: "Que importa quem fala, disse alguém, que importa quem fala", e ao mesmo tempo grifar uma indiferença que, segundo Foucault, pode ser, ainda agora, um dos "princípios éticos fundamentais da escrita contemporânea" (FOUCAULT, 1992, p.34).

[...] ir à procura daquilo que é mais dificil de notar, o mais oculto, o que dá mais trabalho a dizer e a mostrar, enfim o mais interdito e o mais escandaloso. Uma espécie de injunção de desentranhar a parte mais noturna e mais quotidiana da existência (com risco de lá descobrir. por vezes as figuras solenes do destino) vai traçar aquela que é a direção para que pende a literatura desde o século XVII, desde que é literatura no sentido moderno do termo. Mais do que uma forma específica, mais do que uma relação essencial com a forma, é este constrangimento, eu ia dizer esta moral, aquilo que a caracteriza e que até nós transportou o seu imenso movimento: dever de dizer os mais comuns dos segredos. A literatura não tesume por si só esta grande política, esta grande ética discursiva; também não se the reconduz inteiramente; mas é ai que ela tem o seu lugar e as suas condições de existência (FOUCAULT, 1992, p.125-126).

Desta forma, a experiência com a escrita, com essas existências mais infames, tanto no sentido daquelas personagens que habitam o texto quanto nas experiências-limite com a própria linguagem, parece se descolar do tema da expressão e passa a se referir, cada vez mais, a si mesma - então, que importa quem fala? -, um texto que parece apontar para o seu próprio desaparecimento, como um morrer do próprio texto, um cavo, feito uma "dobra gramatical" (essa expressão também é de Michel Foucault), que promove certa escavação da experiência, algum conflito que seja. Ou se pensarmos numa escrita, de fato, mais perto da morte, no esteio das noções sobre a morte do autor, o apagamento do nome, sobre, principalmente, uma idéia de singulatidade que agora se dá na ausência, na falta, e tudo num desdobramento sem fim e sem alcance. Como diria Roland Barthes, "puro gesto de inscrição", um campo sem origem, ou pelo menos uma origem que seja a própria linguagem, e só nela, mesmo que também, continuamente, seja aquilo mesmo o que questiona toda origem (BARTHES, 2004, p.61). É uma questão de abertura, de se colocar numa outra experiência com o espaço - e espaço aqui entendido no sentido simbólico / imaginário da construção de um espaço próprio, no texto -, como diz Foucault em $O$ que é o autor?: ' $\mathrm{Na}$ escrita, não se trata da manifestação ou da exaltação do gesto de escrever, nem da fixação de um sujeito numa linguagem; é uma questão de abertura de um espaço onde o sujeito de escrita está sempre a desaparecer" (1992, p.35). 
E para ampliar ainda mais o problema, pensar que essa imagem de um sujeito que desaparece na escrita, de uma destruição da voz e do corpo que escreve, de uma ausência primeira que daria condição a qualquer discurso, pode ainda nos enviar à proposta de Giorgio Agamben, em seu livro Profanações, a idéia que passa pelo autor como gesto, o autor que, de uma certa forma, habita os limites do texto apenas por ser essa pura ausência do gesto, uma espécie de gesto ilegivel e secreto que, só ele, torna a leitura possível. Desta forma, um mesmo gesto, que é capaz de negar toda importância à identidade, ao nome do autor, também afirma sua irredutivel necessidade para que a leitura se dê, para que o encantamento, para que a magia seja possível. Como nas palavras de Michel Foucault, reproduzidas por Agamben, "a marca do escritor não é mais que a singularidade de sua ausência" (FOUCAULT, 1992, p.36), o que de outra forma é como dizer que a singularidade está no gesto, no vazio, no sem origem. A partir disso, o autor, esta presença-ausência do gesto, pode ser pensado como mais uma vida infame, um "poema-vida", talvez, uma "existência-clarão". Como no dito de Agamben, "exactamente igual que el infame, el autor está presente en el texto solamente en un gesto, que hace posible la expresión en la medida misma en que instaura en ella un vacío central"' (AGAMBEN, 2005, p.87).

Por fim, penso no bonito texto de Michel Foucault, "Eurídice e as sereias"': não seria esse gesto ilegível semelhante ao canto das sereias? Elas que "são a forma inexeqüível e proibida da voz atraente" (1990, p.53), mas que não são mais que canto. Por outro lado este gesto que não é mais que puro gesto, que é pura ausência de voz, de canto, de nome, mas que ao mesmo tempo é um gesto atraente, um convite, um "grato vazio da escuta". No texto de Foucault, o canto das sereias - o que também procuro ler como gesto - seduz não tanto pelo que se deixa ouvir quanto por aquilo

${ }^{4} \mathrm{O}$ texto de Michel Foucault, Euridice e as sereias, que faço uso aqui, consta em $\mathrm{O}$ pensamento do exterior. Tradução Nurimar Falci. São Paulo: Princípio, 1990. que fica em segredo nas palarras, como se todo encantamento estivesse na promessa do que será este canto, no seu por vir, assim também, como se cada gesto assegurasse um segredo inviolável que se desdobra num outro gesto-segredo e assim num movimento sem fim nem começo. Depois, esse canto nada mais é do que atração do canto, nada mais que canto e por essa razão - assim como o gesto do autor -, quase um silêncio, um canto sem palavras, um vazio, uma ausência de canto, feito um "rumor", um canto limite e impossível. Cito Foucault: "Esta voz que 'canta sem palavras' e que deixa ouvir tão pouco não é por acaso a das sereias, das quais toda sua sedução consiste no vazio que abrem, na imobilidade fascinante que provocam naqueles que as escutam?" (FOUCAULT, 1990 , p.57).

Então para tocar mais perto, mais especificamente na narrativa brasileira contemporânea, por aqui e num sendo, um bom exemplo é o trabalho-gesto do escritor Evandro Affonso Ferreira. Trabalho que, a meu ver, monta uma perspectiva interessante a uma idéia de território e memória, um lugar que é todo sem e infame, quando de fato parece não haver nenhum lugar nem mais nada, talvez nem a própria narrativa esteja ali, apenas gesto, este canto limite e impossível. Um movimento que é todo ele de desaparecimento, de morrer do próprio texto, como se fincado ainda, e insistente, numa radicalidade sem par com a linguagem. Como diz Roland Barthes (2004, p.88), "é necessátio exceder a língua, manter-se em sua margem suplementar, isto é, no seu infinito sem profundeza". Depois, a imagem talvez seja a de um rodopio, um gesto de repisar a palavra, e sempre, para um texto que se move na página, e dela para seus outros livros, e de um para o outro, numa sugestão

"Utilizo o termo "rumor" na concepção de Roland Barthes, no seu livro O rumor da língua, no sentido de um ruído que, de certa forma, é uma ausência de ruído, como o barulho daquilo que funciona bem, mas que também é um barulho impossível que faz "ouvir a própria evaporação do barulho: o tênue, o camuflado, o fremente" (Tradução Mátio Laranjeira. 2.ed. São Paulo: M. Fontes, 2004. p. 94) 
que é construir o livto único, o livro total, o livro qualquer-coisa completo e, se assim, o livro que não há; o livro que é não menos que um desaparecimento, uma morte do livro, uma morte da linguagem, uma morte da literatura para dar-lhe potência. $E$ ainda mais se, num tisco, tomar-se o sentido da experiência limite com a linguagem de Evandro, para uma gagueira absoluta, um plano absoluto do anodismo, nesta sempre "repetição do Diferente", numa idéia de "reduplicação do Outro". Cito Deleuze, em Crítica e Clinica, sobre uma idéia da gagueira:

É o que acontece quando a gagueira já não incide sobre palavras preexistentes, mas ela própria introduz as palavras que ela afeta; estas já não existem separadas da gagueita que as seleciona e as liga por conta própria. Não é mais o personagem que é gago de fala, é o escritor que se torna gago da lingua. ele faz gaguejar a língua enquanto tal. Uma linguagem afetiva, intensiva, enão mais uma afecção daquele que fala (DELEUZE, 1997, p.122).

A composição do quadro é a de um cenário vazio, escuso, torpe, tosco, bruto, rude. Se as personagens se apontam anódinas, a narrativa é o seu sem, porque soltos no mundo não são mais que

"Estas são expressões de Gilles Deleuze na sua leitura de certa condição do "duplo" em Michel Foucault. O "duplo" como uma interiotização do lado de fora, como uma "reduplicação do Outro", uma "repetição do Diferente". (Foucault. Tradução Cláudia Sant'Anna Martins. São Paulo: Brasiliense, 2005. p.105)

${ }^{7}$ Faço referência aqui a uma pequena nartativa de Kafka Um artista da fome que consta no livro Um artista da fome / A construção (trad. Modesto Carone. São Paulo: Cia das Letras, ano 1998). Nesta narrativa, Kafka elabora uma destas suas personagens de vidas infames: um homem, artista de circo - jejuador -, é esquecido numa jaula por ter ultrapassado os prazos sem comer de uma forma tão radical que ultrapassa também os prazos de memória das pessoas do circo e, principalmente, de seus visitantes: "Tente explicar para alguém a arte do jejum! Não se pode explicá-la para quem não a sente" (KAFKA, 1998, p.34). Assim, retirado todo o caráter messiânico e judaico da narrativa, Kafka insere, ao final, o nó da infâmia numa fala do jejuador: "Porque eu não pude encontrar o alimento que me agrada. Se eu o tivesse encontrado, pode acreditar, não teria feito nenhum alarde e me empanturrado como você e todo corpos vazios, quase giróvagos. Todos, de alguma forma, a exemplo das personagens infames e disformes citadas anteriormente Odradek, Gregor Samsa e o Corcundinha - são "artistas da fome ${ }^{7 \text { ", }}$ sem comida ou prazer em comer. São personagens que também estão desenhadas sob uma linha de contorno, uma desaparição, uma linha quase tênue, ou nenhuma linha quase nada no que trataria de alguma noção fincada da experiência como aquilo que se incorpora, que se estabelece no corpo como uma memória, um vestigio, ao menos. $\mathrm{E}$ sem exceção, as personagens de Evandro Affonso Ferreira estão desvinculadas, e parece que há em todas elas uma impossibilidade de gritar alguma revolta, mas ao mesmo tempo não se conformam; a impossibilidade da vontade de um não, mas também de um sim, um tudo bem, um pode ser, um deixemos como está. Elas estão simplesmente, vacantes, não estando; e aparentemente impedidas de fazer qualquer escolha. Se assim como as personagens de Kafka, - Odradek, da narrativa "A preocupação do pai de familia", publicada em Um Médico Rural; já citada acima num apontamento de Benjamin, também e ainda o seu conhecido Gregor Samsa, de sua mais famosa novela, A metamorfose. O primeiro, aquele objeto sem forma e um sem nome, porque não se sabe a origem, algo próximo a um carretel de linha, achatado, de fios remendados de todas as cores, algo próximo a forma de uma estrela, talvez, mas ainda um nome que não aponta a lugar nenhum e que faz um homem comum, pai de familia, temê-lo. De outro lado, Gregor Samsa também é um destes seres, agora um inseto monstruoso, resultado de certos sonhos

mundo." (KAFKA, 1998, p.35) Walter Benjamin em seu texto sobre Kafka (Franz Kaffea. A propósito do décimo aniversário de sua morte in Magia e técnica, arte e política: ensaios sobre literatura e história da cultura. Tradução Sérgio Paulo Rouanet. 7 ed. São Paulo: Brasiliense, 1994) diz que "Nenhuma de suas criaturas tem um lugar fixo, um contorno fixo e próprio, não há nenhuma que não esteja ou subindo ou descendo, nenhuma que não seja intercambiável com um vizinho ou um inimigo, nenhuma que não tenha consumido o tempo à sua disposição, permanecendo imatura, nenhuma que não esteja profundamente esgotada, e ao mesmo tempo no inicio de uma longa jornada. Impossivel falar aqui de ordens e hierarquias." (p. 143) 
intranqüilos, que paira dentro do quarto, no meio da casa de uma familia comum, a sua, como um nome secreto, um sem, um emperro e uma criatura inexpressável, um transtorno, mas também e principalmente um abandono.

Estava todo coberto de poeira; sobre as costas e pelos lados arrastava consigo fios, cabelos, restos de comida; sua indiferença diante de tudo era grande demais para que, como antes, tivesse ficado de costas e se esfregado no tapete vátias vezes durante o dia. E a despeito desse estado não teve pejo de se adiantar um pouco sobre o assoalho imaculado da sala de estat. (KAFKA, 1997, p.70).

Depois, ainda, Odradek é esse nome inteiro secreto, silencioso, sem origem, que se move, e que espera, que está ali não estando, e espera, e não estando está, perene, fixo, quase morto, anódino, mas está ali, um bastardo, uma espécie de parasita, uma deformação que é ao mesmo tempo perfeita, completa, móvel, sob o corrimão da escada, no sótão, nos corredores, não se sabe ao certo onde, apenas o mesmo perambular anódino por todos os cômodos da casa e pela vizinhança.

Inutilmente eu me petgunto o que vai acontecer com ele. Será que pode morrer? 'Tudo o que morre teve antes uma espécie de meta, um tipo de atividade e nela se desgastou; não é assim com Odradek. Será então que a seu tempo ele ainda irá rolar escada a baixo diante dos pés dos meus filhos e dos filhos dos meus filhos, atrastando atrás de si os fios do carretel? Evidentemente ele não prejudica ninguém, mas a idéia de que ainda por cima ele deva me sobreviver me é quase dolorosa (KAFKA, 1999, p.45).

Odradek é como um gesto, como o canto das sereias, que não se sabe de onde vem, nem para onde vai, mas apenas que está ali, e que se move, silencioso, mudo, feito magia, porque repousa na casa como segredo, como nome secreto, aquele que nunca morre, o gesto ilegivel de um infame, de uma criatura anódina, como também Gregor Samsa. Benjamin diz que "em Kafka as sereias silenciam; elas dispõem de 'uma arma ainda mais terrível que o seu canto... o seu silêncio"' (1985, p.143). Mas se este silêncio ao canto, um segredo ao nome; daí, é Agamben quem diz sobre os nomes secretos:

El nombre secreto es, èn realidad, el gesto con el cual la criatura es restituída a lo inexpresado. En última instancia, la magia no es conocimiento de los nombres, sino gesto: trastorno y desencantamiento del nombre. Por esse el niño nunca está tan contento como cuando inventa uma lengua secreta. Pero su tristeza no proviene tanto de la ignorância de los nombres mágicos como de su dicicultad para deshacerce del nombre que lê há sido impuesto. (AGAMBEN, 2005, p. 24-25).

É este movimento bambo destas personagens de Kafka, assim como também se movem as personagens estrábicas de Evandro Affonso Ferreira, que nos levaria de volta, num contraponto, ao Foucault, o último Foucault do sujeito da "cultura de si", dos "atos de verdade", do "afeto de si para consigo". E ainda sempre voltar a pergunta: qual experiência possivel? Qual dobra possivel? E mais, qual experiência possível, hoje, ao texto que se propõe como desaparecimento, ou morrer do próprio texto a partir de um desenho de personagens anódinas? O próprio Foucault nos aponta, que o tema do retorno a si nunca foi tão presente entre nós como na época helenística e romana e, desta forma, também

${ }^{8} \mathrm{O}$ termo grego parrbesía é amplamente citado e desenvolvido por Foucault nas suas aulas no College de France, no ano de 1982, principalmente na segunda hora da aula do dia 3 de março e na aula do dia 10 de março. Neste trabalho utilizo parrhesía apenas no sentido de um franco falar, mas é importante lembrar que apenas essa definição, de longe, não esgota o termo aqui em questão. Cito algumas definições extraídas do próprio texto de Michel Foucault: "A parrbesia é, no fundo, o que corresponde, do lado do mestre, à obrigação de silêncio do lado do discípulo. Assim como o discípulo deve calar-se para operar a subjetivação de seu discurso, o mestre, por sua vez, deve manter um discurso que obedece ao principio da pambesia, desde que pretenda que o que ele diz de verdadeiro torne-se enfim, ao termo de sua 
sinaliza para o que seria o seu desaparecimento, assim como o de qualquer idéia de parrbesía ${ }^{8}$, ou seja, o nosso falar franco, que pode estar vinculada ainda a uma atitude moral, do silêncio com exercício de memória, da vida como prova - a necessidade de uma tékbne da existência, de toda uma noção de "cuidado de si" que teria que ser regra coextensiva à própria vida. Como nas palavras de Foucault, em A hermenêutica do sujeito: "O cuidado de si é uma espécie de aguilhão que deve ser implantado na carne dos homens, cravado na sua existência, e constitui um princípio de agitação, um princípio de movimento, um princípio de permanente inquietude no curso da existência" (FOUCAULT, 2004, p.11).

\section{1 "VIDAS DESENGRAÇADAS": ALGO DA NARRATIVA DE EVANDRO AFFONSO FERREIRA}

Um bom exemplo, em movimento contrário ao que está apontando acima, ao tomar como motor o trabalho em rodopio do escritor Evandro Affonso Ferreira, é dizer das existências e experiências precárias de suas personagens, que chamei estrábicas. Todas elas estão recheadas de vazio, é esta a imagem: um recheio de nadas. $\mathrm{E}$ são, assim, uma repetição incessante de elementos anódinos, em si, para tentar negar os seus desamparos. Entre várias, uma das mais vilipendiadas é a sua personagem Seleno Selser, que

ação e direção, o discurso verdadeito subjetivado pelo discípulo. Etimologicamente, parrbesía é o fato de tudo dizer (franqueza, abertura de coração, abertura de palavra, abertura de linguagem, liberdade de palavra). Os latinos traduzem geralmente parthesia por libertas. É a abertura que faz com que se diga, com que se diga o que se tem a dizer, com que se diga o que se tem vontade de dizer, com que se diga o que se pensa dever dizer porque é necessário, porque é útil, porque é verdadeiro. Aparentemente, libertas ou parthesia é essencialmente uma qualidade moral que se requer, no fundo, de todo sujeito que fala." (A hermenêutica do sujeito. Tradução Márcio Alves da Fonseca, Salma Tannus Muchail. São Paulo: M. Fontes, 2004. p.440).

Rev. MOARA Belém in $31 \quad$ p. 127-150 jan/jun., 2009. está em seu livro Araã!, publicado em 2003. Viúvo que completara 70 anos, vendedor de enciclopédias, Seleno Selser mora de favor com o genro e a filha; sofre de inchaço nos pés, dores nos rins, dores na bexiga, dores na coluna, reclama desânimo, lamuria o tempo inteiro todas as suas desesperanças para todos os lados e está sempre às voltas com o que chama de sua "solidão primitiva": as saudades de Mégara", sua mulher; que é ao mesmo tempo mito e aderência ao ordinário, metafísica e fato, anodismo e nome secreto, um segredo, que pode determinar um campo de possíveis, aquilo que pode levar a magia (e a literatura, o gesto, talvez seja isso, provocar ainda alguma magia que pode estar presente apenas nos nomes secretos). Numa passagem do livro, diz disto a que chama de "vida desengraçada", que é uma ótima expressão para renomear o que seriam as "vidas infames", de Foucault, e toda uma problemática outra para este Hermenêutica:

Títio dia hoje daqueles... ih dor no peito cuidado amigo... sei... consulta marcada amanhã... cardiologista... concordo, declínio da existência... último quartel da vida... sim verdade nossas almas muito raramente estão preparadas para ela morte; obrigado Títio huifa! suco sempre gostoso gelado; vida cada vez mais desengraçada; tudo ficando carrancudo, entroviscado; desde que minha Mégara me deixou meus dias amanhecem com claridade frouxa; vivo atormentado pelas fustigações da saudade. (FERREIRA, 2003, p.114-115)

Desta maneira, o que vai parecer ou ficar evidente neste Seleno Selser de Evandro Affonso Ferreira, em vários de seus

${ }^{9}$ O nome Mégara, utilizado por Evandro Affonso Ferreira para nomear a saudade que faz Seleno Selser padecer uma dor inominável ou a sua "solidão primitiva", segundo a mitologia grega, é o nome da filha de Creonte, rei de Tebas. Este fez com que Mégara desposasse Héracles para tecompensá-lo pela vitótia sobre os Mínias de Orcómeno. Héracles mais tarde foi acometido de loucura por causa de uma intervenção de Hera e, num surto, matou todos os filhos que tivera com Mégara (GRMAL, Pierre. Dicionário da Mitologia Grega e Romana. Tradução de Victor Jabouille. Rio de Janeiro: Bettrand Brasil, 1992). 
entornos, é, primeiro, uma certa desfunção ao mundo como lugar, como lugar afetivo / efetivo da experiência; e, segundo, a si mesmo como sujeito da experiência. Nisso, em todos os problemas que se montam sozinhos, desde a profissão completamente inexistente, a de vendedor de enciclopédias (como se perguntasse para que servem este chumaços de livros, peso e entulho, em verbetes fixos e obsoletos ao tempo do imediato?), aos adoecimentos da alma, aos cansaços, à sua vida desistida. Depois, ainda, fica a questão: qual lugar - e afecção - ou qual senso, num mundo de vidas negociadas à solapa de um mercado monstruoso e desumano, àquele que tenta comerciar o imprestável, as enciclopédias, como experiência para a vida? O que leva a uma segunda questão, desta vez ao texto de Evandro Affonso Ferreira e o que ele propõe como discurso, como narrativa, como literatura etc: qual texto possível à narrativa destas vidas infames senão aquele que é apenas gesto, e que seria também num mesmo movimento, como gesto - uma profanação?

Isto fica muito pertinente verificar na agitação textual, em gesto de rodopio, que Evandro Affonso Ferreira elabora no seu trabalho. Tanto na condução de uma idéia que está como passagem furiosa de um livro a outro, de um texto a outro, de uma personagem a outra, quanto no dentro / fora em suas próprias personagens anódinas, fixadas em si mesmas, descoladas de qualquer idéia de experiência como aderência, como perturbação da história, como deslocamento incessante. Um movimento claramente contrário àquele que Michel Foucault identifica, no seu gesto de retornar aos gregos, em A Hermenêutica do sujeito, como necessário para uma idéia-proposição de um conhecimento útil, que seria um conhecimento de si e de controle e influência sobre a própria vida, no sentido de produzir uma mudança, uma perturbação, uma transformação no modo de ser do sujeito, ou, como diz Foucault: "é preciso, durante toda a vida, voltar a atenção, os olhos, o espirtito, o ser por inteiro enfim, na direção de nós mesmos. Trata-se da grande imagem da volta para si mesmo" (2004, p.254). E sobre essa idéia da volta sobre si mesmo, Foucault identifica uma outra imagem para contrapô-la , que pode ser também identificada nas personagens de Evandro Affonso Ferreira, que seria a "imagem do pião". Segundo essa imagem, o giro do pião sobre si seria exatamente o movimento que deveríamos evitar dentro desta idéia de volta do sujeito sobre si, de voltar os olhos e a atenção sobre si, numa perspectiva que seria a de uma transformação-movimento do sujeito. Cito Foucault:

O pião gira sobre si, mas gira sobre si justamente como não convém que giremos sobre nós. O que é o pião? É alguma coisa que gira sobre si por solicitação e sob o impulso de um movimento exterior. [...] Ora, contrariamente ao movimento do pião, a sabedoria consistirá em não se deixar jamais ser induzido a um movimento involuntário por solicitação ou impulso de um movimento exterior . pelo contrário, será preciso buscar no centro de nós mesmos o ponto no qual nos fixaremos e em relação ao qual permaneceremos imóveis. É na direção de si mesmo ou do centro de si, é no centro de si mesmo que devemos fixar nossa meta. (FOUCAULT, 2004, p.154)

Desta forma, a imagem sugerida aqui para as personagens de Evandro Affonso Ferreira, como Seleno Selser, a partir da "imagem do pião", talvez seja essa da impossibilidade de uma escolha, a impossibilidade de um giro sobre si, espontâneo; o que impede uma volta em atenção e cuidado sobre si, para provocar, ao contrário disso, um sentido de movimento que se impõe por uma solicitação externa, por uma força de impulso exterior, feito um comando, um giro calculado e sem tiscos, que ressalta ainda mais a condição de desamparo, de precariedade e de imobilidade das personagens. É esse movimento primeiro e determinante que pode resultar do gesto do autor, desse traço invisível e ilegível, que dá o contorno preciso das personagens infames, das existências deformadas, techeadas de nadas, esses quase, sem origem e de nomes quase sempre secretos. Cito dois trechos de falas da personagem Seleno Selser; primeiro, apontando ao seu abandono e à sua fragilidade diante da morte (que é uma recorrência em toda a narrativa e em volta de Seleno Selser: todos tendem a ir morrendo, numa seqüência de falências, de sumiços): 
Agora sim me alimentando um pouco mais ufa! pensei que não fosse agüentat, desnutrição, três primeiros dias hã jejum absoluto; sim amigo oigalêl Coração surunganga mesmo; impossível desvendar enigma do sofrimento imerecido; a brevidade da vida humana evidencia a nossa insignificância; mas não vou chafurdar num lodaçal de autopiedade; Freud uma vez disse citando alguém cujo nome escorregou da memória, que todo homem tem de descobtir por si mesmo de que modo específico ele pode ser salvo; não vivemos no Olimpo, devemos assumir o ônus da vida terrena (FERREIRA, 2003, p.45).

Segundo, a sua ocupação inoperante e sem lugat, a de quem lida com o imprestável na esfera incessante de um comércio sem compra, sem venda; uma ocupação ao desnecessátio: a de vendedor de enciclopédias.

Sim senhor doutor advogado, papel alta alvura, acabamento de primeiríssima, quase quinze mil páginas de prestimoso saber; tive a pachorra de contar, cinqüenta e sete páginas falando apenas de Direito: etimologia conceito classificação estrutura eficácia fontes aplicações métodos ufa! assunto esgaravatado de fio a pavio, ou, lançando mão do latinismo aliás familiar aos senhores, ab imo ad summum; cinco vezes, podemos fazer em cinco vezes sim senhor; cheques prédatados. (FERREIRA, 2003, p.14)

Uma outra personagem de Evandro Affonso Ferreira, para encerrar o nó dos exemplos, aparece em seu livro Zaratempô!, publicado em 2005. Esta personagem empresta sua voz narradora a uma mínima inserção narrativa dentro da outra, maior, a do livro, como uma espécie de intervalo, suspensão ou desordem. Evandro Affonso Ferreira costuma montar dentro de seus livros outros textos, menores, ínfimos, notas irrisórias, apêndices, sobras textuais, dobraduras, estocadas nervosas completamente descoladas da narrativa principal do livro, o que ele próprio nomeia de mini-contos; esta recorrência a que faz uso termina por estar ali como um recurso textual-narrativo, um recuo de olhar ou uma aproximação beligerante da vista, uma microcospia a algum caráter inominado e mais tosco ainda da vida, dos entes; é de fato um desvão, um buraco, uma queda no texto. O mini-conto em questão é intitulado de

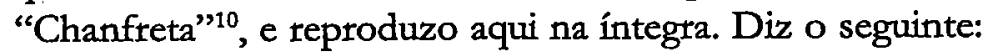

\section{CHANFRETA}

Tal qual Dom Quixote condenado ao tidículo, pasmosamente velho jogando dominó na praça contando façanhas imaginárias: vida deste enganzopador aqui sempre marasmada hã passos contados tudo numa lenteza que só vendo; nenhuma aventura amorosa capaz de estimular a atividade criadora de um cordelista que fosse; nenhum heroísmo miúdo ao menos ufa puxar num átimo braço de cego que atravessa esquina ui peraí sinal aberto; vida toda eclipsado pela proeza alheia; nenhuma noite em claro bebendo fumando jogando bilhar; nunca dia nenhum ligação inesperada ei pai carro bateu perda total peito enfaixado pronto-socorro venha depressa; também diacho arremedei bruxo aquele do Cosme Velho hã não transmiti a nenhuma criatura o legado da nossa miséria; [...] velhos safados todos esses companheiros de dominó na praça sabem da patranhice mas vivem pedindo ei Permínio conta outta vez histótia aquela de quando você quarenta anos atrás... sim suruba na casa dum conde cônsul sabe-se lá; final insosso este envelhecer sem vivência, Sherazade versão masculina inventando histórias para não morret ao realengo num canto qual lobo da estepe; se pelo menos gravidez daquela namorada há meio século não tivesse sido alarme falso teria história real pra contar, aborto mal-sucedido talvez, morte prematura dela namorada quem sabe provocaria escândalo, médico famoso, teria guardado

\footnotetext{
${ }^{10}$ Chanfreta é uma palavra que consta do dicionátio de palavras sonoras elaborado pelo próprio Evandro Affonso Ferreira. Este dicionário já se alonga a cada livro e já está com quase duas mil palavras. Evandro comenta que tem pretensões de publicálo. Uma pequena mostra deste dicionátio foi publicado na revista Oroboro, n. 08 (Curitiba: Medusa, 2006) dentro de um dossiê que organizei sobre ele. Basta ver, como exemplo mais imediato, os títulos de seus livtos: Grogotó, Erufuê, Araã, Zaratempô e Catrâmbias, todas palavras elabotadas por ele, retiradas de um uso popular, algumas vezes, e colocadas num outro sentido, ou num mesmo. Palavras que sempre apontam a uma idéia, a meu ver, dos nomes secretos; palavras que guatdam em si um não-sentido da magia, aquilo que ainda pode conter magia. (Chanfreta, segundo o dicionário de EAF, significa chacota, zombaria.)
} 
comigo até hoje recortes de jomais, meu nome neles todos, caixa alita, prova irrefutável; triste envelhecer diacho mais triste ainda depois de velho jogar anzol no passado neca neres de fisgar uma única emoção pretérita; [...] setenta anos de vida enfadonha; nenhuma fratura exposta num jogo de campeonato escolar; nenhum puxão de orelha da professora; nenhum coma alcoólico; triste demais fim da estrada olho pto espelho retrovisor neca nada tudo embaçado reflexo nenhum; não tivesse faltado, enxaqueca, quando chefe da repartição aquele que trinta e cinco anos atrás chegou na sala gesto tresloucado atirando a esmo huifa história agora seria outra; pronto, dominó por hoje chega hã espero não precisar repetir mais uma vez história dela minha primeira mulher infiel aquela que pressionada pelas circunstâncias se matou, arsênico, sei lá de tepente velhote aí colete surrado debutando na praça já leu Flaubert ixe chacotas infinitas. (2005, p.20-22)

A questão sobre a qual Evandro Affonso Ferreira monta o seu trabalho e parece nos propor pensar, e tomo como uma articulação propositiva para juntar ao Foucault de A Hermenêutica do sujeito, é uma discussão sobre o caráter da experiência contemporânea, como vida infame, como devir, como sujeito e, por fim, também, é claro, como elemento questionador do lugar da literatura como problema, como experiência e como experiência textual, discurso etc, sempre como um gesto radical ao que seria a experiência pura, como um estatuto original da experiência. A questão talvez seja: o que se pode esperar de uma proposta de experiência contemporânea que exala um fecho, uma porta fechada às heterogeneidades e ao mundo como uma raspa de nossas vivências; ao mesmo tempo em que coloca esta experiência como anódina e sem aderência e como também uma que se fixa numa superficie sem fundo da existência. Agamben vai dizer que o velho sujeito da experiência está morto, ou que, talvez, existam agora dois sujeitos: um que se aproximaria à imagem de Dom Quixote, e seria "o velho sujeito do conhecimento", este sujeito que pode fazer experiência sem jamais retê-la. E também "tal qual Dom Quixote", o narrador de "Chanfreta", de Evandro Affonso Ferreira, não passa de um "condenado ao ridículo, pasmosamente velho jogando dominó na praça contando façanhas imaginátias" -, o sujeito exproptiado da experiência, aquele que habita um fantasma. Um outro, que seria o seu inseparável companheiro Sancho Panfa, escudeiro às avessas, figura "o velho sujeito da experiência", aquele que apenas pode ter experiência, mas nunca fazê-la. Diz ainda Agamben que:

Todo discurso sobre a experiência deve partir atualmente da constatação de que ela não é mais algo que ainda nos seja dado fazer. Pois, assim como foi privado da sua biografia, o homem contemporâneo foi expropriado de sua experiência: aliás, a incapacidade de fazer e transmitir experiência talvez seja um dos poucos dados certos de que disponha sobre si mesmo. (AGAMBEN, 2005, p.21)

Talvez, assim, partindo do trabalho em rodopio do texto de Evandro Affonso Ferreira e tomando nele como antecipação da experiência-limite alguma morte, algum morrer, do sujeito e logo da linguagem, mover o rodopio ao contrário seria aceitar a aposta da sugestão de Foucault ao propor a transferência da experiência moderna (ao homem contemporâneo) como experiência contemporânea, na falta de um termo melhor, àquilo que seria alguma resistência, "um afeto de si para consigo", uma possibilidade de se fazer como dobra, recompor uma organização ética do sujeito nas sobras de sua subjetividade, que seja, para provocar alguma perturbação na histótia. Tudo isso, provável, movido naquilo a que Foucault chama de pensamento exterior, uma experiência exterior e limite, para fora do homem, num movimento infinito, um silêncio, o fora, também pensado como uma política do desejo.

\section{REFERÊNCIAS}

AGAMBEN, Giorgio. Infância e História (Destruição da Experiência e Origem da História). Tradução de Hentique Burigo. Belo Horizonte: UFMG, 2005. 
Profanaciones. Tradução Flavia Costa e Edgardo Castro. Cótdoba: Adriana Hidalgo, 2005.

BARTHES, Roland. O Rumor da Lingua. Trad. Mátio Latanjeira. 2. ed. São Paulo: M. Fontes, 2004.

BENJAMIN, Walter. Magia e Técnica, Arte e Politica: ensaios sobre literatura e bistória da cultura. Tradução de Sérgio Paulo Rouanet. 7. ed.São Paulo: Brasiliense, 1985. (Obras escolhidas ; v. 1)

. Rua de Mão Única. Tradução de Rubens Rodrigues Torre Filho. São Paulo: Brasiliense, 1987.

BLANCHOT, Maurice. O livro por vir. Tradução Leyla PerroneMoisés. São Paulo: M. Fontes, 2005.

DELEUZE, Gilles. Crítica e Clínica. Tradução Peter Pál Pelbart. São Paulo: Ed. 34, 1997. Foucault. Tradução

Cláudia Sant'Anna Martins. São Paulo: Brasiliense, 2005.

FERREIRA, Evandro Affonso. Araã! São Paulo: Hedra, 2003. Zaratempô! São Paulo: Ed 34, 2005.

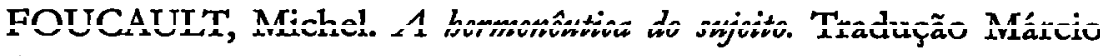
Alves da Fonseca, Salma Tannus Muchail. São Paulo: Martins Fontes, 2004. (Tópicos)

. O que é um autor? Tradução António Fernando Cascais e Edmundo Cordeiro. Lisboa: Passagens, 1992.

São Paulo: Princípio, 1990.

O pensamento do exterior. Tradução Nurimar Falci.

GRIMAL, Pierre. Dicionário da Mitologia Grega e Romana. Tradução de Victor Jabouille. Rio de Janeiro: Bertrand Brasil, 1992

KAFKA, Franz. Um artista da fome e $A$ construção. Tradução e posfácio Modesto Carone. São Paulo: Companhia das Letras, 1998.

- A metamorfose. Tradução e posfácio Modesto Carone. São Paulo: Companhia das Letras, 1997.

- O médico rural: pequenas narrativas. Tradução e

posfácio Modesto Carone. São Paulo: Companhia das Letras, 1999. 